\title{
«AQUELLOS FURIBUNDOS Y TERRIBLES GOLPES»: LA EXPRESIÓN DEL COMBATE SINGULAR EN LOS TEXTOS CABALLERESCOS
}

\author{
José JULIO MARTín ROMERO \\ Universidad de Jaén
}

\section{EL COMBATE COMO UNIDAD TEXTUAL Y SU IMPORTANCIA}

La narración de la batalla es una de las señas de identidad de los libros de caballerías, y, por tanto, un elemento esencial en ellos ${ }^{1}$. En su ya clásico estudio «Las armas en el Amadís de Gaula», Martín de Riquer destacó la importancia de los enfrentamientos armados en estas obras, pero también indicaba cómo al lector moderno «todas estas batallas le parecen iguales, aunque de hecho no lo son» ${ }^{2}$. No hubo de ser así durante nuestros Siglos de Oro, como demuestra el testimonio del ventero cervantino:

Porque, cuando es tiempo de la siega, se recogen aquí, las fiestas, muchos segadores, y siempre hay algunos que saben leer, el cual coge uno destos libros en las manos, y rodeámonos dél más de treinta, y estámosle escuchando con tanto gusto que nos quita mil canas; a lo menos, de mí sé decir que cuando oyo decir aquellos furibundos y terribles golpes que los caballeros

${ }^{1}$ César Domínguez considera que la biografía heroica del caballero «se articula mediante la sucesión de secuencias de tipo bélico», y que asimismo «la acumulación de actividades guerreras victoriosas perfilan el currículum del héroe y determinan su fama para la posteridad», vid. César Domínguez, «'De aquel pecado que le acusaban a falsedat'. Reinas injustamente acusadas en los libros de caballerías (Ysonberta, Florençia, la santa Enperatrís y Sevilla)», Literatura de caballerías y orígenes de la novela, Rafael Beltrán, ed., Valencia, Universitat de València, 1998, págs. 159-180 (cito la pág. 160).

${ }^{2}$ Martín de Riquer, «Las armas en el Amadís de Gaula», Estudios sobre el Amadís de Gaula, Barcelona, Sirmio, 1987, pág. 60. La misma opinión expresa Daniel Eisenberg: «Even the various and seemingly endless and uniform tournaments actually have subtle differences within them to maintain the readers' interest, just as each soccer game, for example, is different, though to one who has not seen many games an does not understand the strategy, they will all be alike.» (Romances of Chivalry in the Spanish Golden Age, Newark, Delaware, Juan de la Cuesta, 1982, pág. 73). 
pegan, que me toma gana de hacer otro tanto, y que querría estar oyéndolos noches y días ${ }^{3}$.

Este ventero, que con tanto placer se sumerge en la narración de los combates, era capaz de percibir las diferencias y matices que singularizaban cada enfrentamiento bélico. Pero «aquellos furibundos y terribles golpes» que tanto entusiasmo despertaban en los lectores de entonces han pasado a ser considerados como un interminable cúmulo de repeticiones. Ello ha provocado que la construcción literaria del combate haya sido paradójicamente uno de los aspectos menos estudiados por los críticos, pues todavía hoy se mantiene la idea de que la batalla, como pieza textual, carece de toda originalidad, idea que se deriva, por una parte, de la casi ineludible victoria del héroe y, por otra, de la aparición de tópicos que pueden ocultar la originalidad del texto. Con respecto al inevitable triunfo del protagonista, no hay que olvidar, sin embargo, que el proceso de defensa y ataque — no sólo el desenlace - resulta pertinente para la correcta valoración de su evolución heroica; por lo tanto, resulta necesario prestar atención a todos los detalles del combate, detalles que pueden parecer irrelevantes, pero que proporcionan información valiosísima para evaluar correctamente una determinada hazaña.

Por otra parte, con respecto a la aparición de tópicos, hay que tener en cuenta que, si las descripciones de tormentas marinas «eran una verdadera piedra de toque para calibrar la capacidad estilística de los autores de entonces» en las narrativas bizantina, picaresca y otros géneros novelescos, tal como afirma José M. ${ }^{a}$ Micó$^{4}$, lo mismo podría decirse de la narración del combate en los libros de caballerías, que, junto con otros motivos (la écfrasis o el amanecer mitológico), se convirtió en un ejercicio estilístico.

El autor de estos textos pretendía dejar su marca personal en el relato de esas batallas que hoy día tan tediosas pueden llegar a parecer a los impacientes lectores de nuestra época. A medida que avanza el siglo XVI, el escritor de libros de caballerías es cada vez más consciente de su categoría de creador literario y va confiriendo a sus textos mayor grado de artificio artístico. El combate se convierte así en un momento en el que el autor ensaya sus dotes literarias. Cada texto revela un juego de tensiones con la tradición de la que deriva, juego de tensiones apoyado en la presencia, ausencia o transformación de determinados tópicos; conocer estos tópicos se convierte en tarea necesaria para determinar la originalidad de un texto, porque, por mucho que se parezcan, no

${ }^{3}$ Miguel de Cervantes Saavedra, El Ingenioso Hidalgo Don Quijote de la Mancha, Florencio Sevilla Arroyo y Antonio Rey Hazas, eds., Alcalá de Henares, Centro de Estudios Cervantinos, 1994, pág. 323.

${ }^{4}$ Vid. la nota 12 (pág. 305) de José M. ${ }^{a}$ Micó en su edición de Mateo Alemán, Guzmán de Alfarache, Madrid, Cátedra, 1998. 
hay dos batallas idénticas, al contrario de lo se que suele pensar. Todo esto hace especialmente interesante el análisis de la composición literaria del combate, pues resulta relevante a la hora de juzgar la actitud de un autor frente a la tradición literaria de la que bebe al tiempo que nos señala las soluciones literarias con las que se resuelve la necesidad de transmitir un proceso, el bélico, especialmente complejo.

\section{APROXIMACIÓN AL ARTE DE LA GUERRA: LA LID SINGULAR}

Aunque los combates que se leen en los libros de caballerías reflejan algunas realidades todavía vigentes en el siglo XVI, sin duda en su conjunto resultaban anticuados, no en vano recogían la tradición amadisiana, heredera, a su vez, de los romans artúricos del siglo XIII ${ }^{5}$.

Con el devenir del tiempo el género fue acogiendo alguna modernización armamentística, si bien apenas cambiaron los modos literarios de combatir. Aparecieron así el ristre, los yelmos con visera e incluso la pólvora, si bien la artillería, —no infrecuente pero tampoco recurrente- se limita a la guerra «guerreada» o colectiva. Por su parte, el ristre o el yelmo con visera -inexistentes en el Amadís de Gaula- no suponían un mundo bélico demasiado opuesto al espíritu de esta obra. En cualquier caso, nunca se pretendió en los libros de caballerías dar una imagen especialmente moderna de la guerra (y mucho menos de las lides singulares). Las raíces artúricas y amadisianas siempre están presentes y, junto con las innovaciones mencionadas, fueron creando una serie de expectativas en el receptor de libros de caballerías. Esas expectativas conforman una especie de arte literaria de la guerra cuyo conocimiento nos ayudará a entender mejor la pasión que los relatos de combates singulares despertaron en los lectores de aquella época.

De acuerdo con Martín de Riquer, en el Amadís de Gaula el combate individual constaba al menos de cuatro momentos:

$1^{\circ}$, los caballeros se acometen a caballo con las lanzas y las quiebran; $2 .^{\circ}$ debido a esta acometida los dos adversarios se desarzonan mutuamente y caen ambos del caballo al suelo; $3 .^{\circ}$, los dos echan mano a la espada y así siguen la pelea, y $4^{\circ}$, uno de ellos se impone sobre su adversario ${ }^{6}$.

${ }^{5}$ Martín de Riquer, op. cit. Sobre el aspecto bélico en la prosa caballeresca del siglo XIV resulta muy interesante el artículo de José Manuel Lucía Megías, «Dos caballeros en combate: batallas y lides singulares en La leyenda del caballero del Cisne y el Libro del caballero Zifar», La literatura en la época de Sancho IV (Actas del Congreso Internacional "La literatura en la época de Sancho IV», Alcalá de Henares, 21-24 de febrero de 1994), Carlos Alvar y José Manuel Lucía Megías, eds., Alcalá de Henares, Universidad de Alcalá de Henares, 1996, págs. 427-452.

${ }^{6}$ Martín de Riquer, op. cit., pág. 61. 
Esta estructura básica procede, como hemos dicho, de la larga tradición de romans artúricos, y se va a mantener en los libros de caballerías posteriores. Claro está, no siempre se dan todos estos pasos; por ejemplo, no siempre se produce el encuentro de lanzas, sino que a veces comienzan directamente a luchar con espadas; o, al contrario, se derrota al adversario simplemente con el primer golpe de lanza. Algunos de estos cambios, a su vez, se terminan convirtiendo en lugares comunes. Así, por ejemplo, llega a ser tópico que ninguno de los caballeros caiga del caballo y la lucha de espadas se lleve a cabo sobre sus cabalgaduras ${ }^{7}$.

El hecho de que ninguno de los contendientes caiga del caballo nos hace pensar en su admirable resistencia y fortaleza. Otras veces se menciona cómo los caballeros se ven forzados a abrazarse al cuello de su cabalgadura para no caer, una forma de indicar la dureza del encuentro ${ }^{8}$.

Pero en otras ocasiones, tal como indica Riquer, caen ambos del caballo de forma que la batalla de las espadas se lleva a cabo a pie ${ }^{9}$. Si el hecho de que los dos se mantengan a caballo indica su fortaleza, también admira el que caigan ambos, siempre que uno de los contendientes sea el héroe; cuando esto sucede, el contrincante aparece, en esa primera fase, a la misma altura del protagonista, lo que indica que nos encontramos ante un guerrero excepcional.

En cualquier caso, sea a pie o a caballo, tras el encuentro inicial con las lanzas la batalla continúa casi inevitablemente con las espadas. Al igual que en el encuentro de lanzas, los caballeros pueden sentir los golpes de forma que

7 «cada uno quebró su lança en muchas pieças en el escudo del otro. Mas no se movió ninguno de ellos de la silla ni se hizieron otro mal y pasaron muy buenos cavalgantes» (Felix Magno, vol. II, pág. 28); «Y aquella gran furia y demasiada fuerça, que una torre bastara a derribar por tierra, no hizo más impresión ni sentimiento en los dos fortísimos guerreros que si sendas rocas fueran» (Espejo de príncipes y caballeros, vol. I, pág. 202); «Y ninguno falleció de su encuentro, que las lanças, aunque gruesas, hechas pieças menudas se esparzieron por el aire, quedando cada uno tan firme en la silla como un marítimo peñasco» (Segunda parte de Espejo de príncipes y caballeros, pág. 32). Sigo las siguientes ediciones: Felix Magno, Claudia Dematté, ed., 2 vols., Alcalá de Henares, Centro de Estudios Cervantinos, 2001; Diego Ortúñez de Calahorra, Espejo de príncipes y cavalleros [El cavallero del Febo], Daniel Eisenberg, ed., 6 vols., Madrid, Espasa-Calpe, 1975; y Pedro de la Sierra, Segunda parte de Espejo de príncipes y caballeros, José Julio Martín Romero, ed., Alcalá de Henares, Centro de Estudios Cervantinos, 2003.

8 «ellos quedaron tan desacordados que si no se abraçaran a los cuellos de los cauallos vinieran al suelo» (Jerónimo Fernández, Belianís de Grecia, Lilia E. Ferrario de Orduna, ed., Kassel, Reichenberger, 1997, vol. II, pág. 45). En otras ocasiones, el impacto es tal, que el guerrero da en el arzón trasero.

${ }^{9}$ «E luego se desafiaron e se arredraron el uno del otro, e diéronse tan grandes golpes que amos a dos cayeron en tierra.» (Tristán, pág. 142); «se encontraron en medio de los escudos [...] de manera que ellos y los cavallos vinieron al suelo, quedando los cavallos muertos y ellos tan sin sentido que los que los vieron los juzgavan sin vidas» (Olivante, pág. 768). Utilizo las siguientes ediciones: Tristán de Leonís, M. ${ }^{a}$ Luzdivina Cuesta Torre, ed., Alcalá de Henares, Centro de Estudios Cervantinos, 1999; Antonio de Torquemada, Don Olivante de Laura, Isabel Muguruza, ed., Madrid, Fundación José Antonio de Castro, 1997. 
tengan que abrazarse a los cuellos de los caballos, o se tuerzan sobre el arzón $\operatorname{trasero}^{10}$.

Se percibe así cómo no todos los golpes son iguales: algunos resultan fallidos, mientras que otros hieren al contrario o destrozan su armamento. Las armas defensivas son especialmente importantes, pero su resistencia (salvo que la magia lo remedie) tiene un límite. Normalmente los yelmos, protectores de la cabeza, son los más difíciles de atravesar, lo cual no implica que no pueda ocurrir. En ocasiones no se quiebran, pero las enlazaduras que lo sujetan se rompen, de forma que el caballero lo pierde, por lo que su situación en el combate resulta crítica:

los lazos del yelmo del emperador del terrible golpe fueron hechos pedaços y le saltó de la cabeça (...). Y cierto, a esta ora, la vida del emperador corría mucho riesgo porque estaua sin escudo y yelmo (...). (Belianís, vol. I, pág. 214)

A veces el impacto de los golpes no consigue quebrar el yelmo, pero sí aturdir —e incluso matar - al guerrero por un traumatismo (también puede destrozarse el cráneo del adversario sin dañar esta pieza de la armadura ${ }^{11}$.

Por otra parte, hay que mencionar el punto débil del yelmo (aparte de las enlazaduras), que es la visera o vista; no nos referimos con visera a la parte del yelmo que se levanta, sino a la abertura (mínima, por otra parte) por la que el caballero puede ver:

Y cerca de sí halló a Feridefonte, que tras él avía ido, y lo hirió de un revés en la visera, que con las centellas que le hizo saltar las cejas le chamuscó, dando con el cuerpo sobre las ancas del cavallo sin ningún sentido. (Segunda parte de Espejo de príncipes y caballeros, pág. 264).

Por esa pequeña abertura puede incluso entrar la espada (o incluso la lanza, en un alarde de puntería), con la casi ineludible muerte del caballero.

Salvo en el caso de que estén encantadas ${ }^{12}$, menos resistentes resultan las

10 «donde se travó una batalla cual jamás en Grecia se avía visto, haziéndose con sus desordenados golpes ora salir de sentido, hora inclinarse las cabeças <basta $>$ [hasta] los pechos, otras vezes hasta las ancas de los cavallos» (Segunda parte de Espejo de príncipes y caballeros, pág. 280).

${ }^{11}$ No es nececesario que el yelmo esté encantado para salvar la vida al héroe, basta con que sea de fino temple o de gran fortaleza; pero el impacto, aunque no cause heridas, llega a aturdir: «Y puesto que el yelmo no fue cortado por su gran fortaleza al sobervio Ardino le convino poner las manos en tierra» (Pedro de Luján, Leandro el Bel, Toledo, Miguel Ferrer, 1563, fol. 65rb.

${ }^{12} \mathrm{El}$ encantamiento de la loriga tampoco impide siempre la muerte. Así sucede en el libro del rey Canamor, en la lucha entre Turián y Diacolo. Diacolo lleva una loriga encantada que «tenía tal virtud que cavallero que la llevasse si spíritu no le falleciesse, no le matarían, ca era muy fuerte, que ninguna arma no le podía empecer» (pág. 85). Pero Turián, sin embargo, es tan temible guerrero que a su contendiente «le hizo perder el sentido y dio con él en tierra muerto, 
cotas de malla y las lorigas, que, falsadas con facilidad, no parecen impedir que las espadas corten y hieran el cuerpo hasta que sangre. Pero, de nuevo, hay que matizar, pues no todas las heridas son iguales. Hay heridas mortales y otras que no son de gran importancia, aunque si son muy numerosas pueden provocar la pérdida de sangre $\mathrm{y}$, por tanto, del conocimiento e incluso de la vida del guerrero.

El escudo también tiene una vida corta. Si, por una parte, esta pieza debía resultar resistente, también había de ser ligera y manejable, pues un escudo demasiado pesado se convertía en un inconveniente ${ }^{13}$. Esa necesidad de ligereza explica por qué se destrozan los escudos con tanta facilidad, y sus pedazos se esparcen por el suelo, junto con las mallas de las lorigas.

Con respecto a las armas ofensivas, ya hemos comentado cómo lo normal es que las lanzas se quiebren del encuentro y se hagan astillas o «menudas piezas». Pero el guerrero también puede perder o romper su espada. Es posible que, tras un golpe especialmente fuerte, la espada quede enganchada en el escudo u otra pieza del arnés del contrario, de forma que no sea fácil recuperarla. También puede darse el caso de que la espada se quiebre por la fuerza de un determinado golpe. Junto con la ruptura o pérdida del yelmo, la pérdida de la espada supone una de las mayores desventajas para un guerrero, y, por tanto, un momento de máximo riesgo. La importancia de la espada para un caballero es enorme (y no sólo por su simbología), ya que es el arma ofensiva de máxima utilidad; por ello, el caballero intentará recuperarla por todos los medios posibles o bien cobrar alguna otra, aunque sea la de su contrincante ${ }^{14}$.

Cuando la duración del combate se alarga, los guerreros pueden necesitar tomar aliento, y se detienen para descansar (la forma más frecuente es apoyar el pecho sobre el pomo de la espada). En esos momentos, los caballeros tienen oportunidad de reflexionar sobre el combate y reconocer el valor y la fuerza de su contrario; también pueden dedicarse a invocar a Dios, a la Virgen, o, en caso de ser paganos, a sus dioses; también pueden recordar a sus amadas. En

que se ahogó en las armas de los golpes que Turián le dio, que nunca dél salió gota de sangre, y assí lo mató» (pág. 87). Sigo la edición de Nieves Baranda, Libro del rey Canamor, Historias caballerescas del siglo XVI, vol. II, Madrid, Fundación José Antonio de Castro, 1995, págs. 3-122.

${ }^{13}$ Sin embargo, ya desde el Amadís de Gaula encontramos escudos de acero, pero normalmente en manos de jayanes, cuya fuerza desmesurada les permite manejarlos fácilmente. Vid. los comentarios de Juan Manuel Cacho Blecua a su edición de Garci Rodríguez de Montalvo, Amadís de Gaula, Madrid, Cátedra, 1991, en la nota 54, pág. 877. Utilizamos esta edición para las citas del presente artículo.

${ }^{14}$ Efectivamente, si uno de los contendientes ha perdido por algún motivo la espada, puede intentar arrebatársela a su contrincante. Claro está, si no lo consigue, se recurrirá a otros métodos como la búsqueda de otras armas, esquivar todos los golpes o comenzar otra etapa del combate: la lucha cuerpo a cuerpo o lucha «a brazos». 
ocasiones el caballero se queja contra sí mismo por no derrotar fácilmente a su contrincante, momento apropiado para hacer recuento de sus hazañas pasadas y contraponerlas a un presente en que no es capaz de salir victorioso. También en esos momentos, los guerreros pueden dialogar, intentar conocer la identidad de su contrario o detener la lucha. Si a pesar de ello, deciden seguir luchando, el combate suele continuar con tanta o más furia que al principio.

Durante el combate, los caballeros en algún momento pueden perder la paciencia y centrarse exclusivamente en el ataque. En esos casos, si el escudo sigue sirviéndoles para algo (lo que no siempre ocurre), lo echan a las espaldas y toman la espada con las dos manos. Recordemos que normalmente la espada se maneja con una sola mano, mientras con la otra se sujeta el escudo. Golpear con las dos manos implica que el guerrero pretende aprovecharse de toda su fuerza. Para ello, si el caballero todavía está a caballo, suele afianzarse bien sobre los estribos, e incluso en ocasiones se pone en pie sobre ellos para que el golpe, desde mayor altura, resulte todavía más efectivo. Este golpe a dos manos puede deberse a un momento de especial furia del caballero o a un deseo de dar fin a la batalla definitivamente:

E Tristán echó su escudo al cuello e tomó el espada con amas manos, e fue a dar a Morlot un gran golpe encima de la cabeça que el yelmo le cortó. (Tristán, pág. 23)

Diziendo esto, se levanta sobre los estribos, y con la espada a dos manos asienta un golpe al Cavallero del Febo sobre su mágico yelmo que los dientes le hizo cruxir unos con otros, y la cabeça le hizo abaxar hasta los pechos. (Espejo de príncipes y caballeros, vol. III, pág. 195)

El qual, pareciéndole que su muerte o vencimiento estava cerca, echó el escudo a las espaldas y todo encendido en ira, tomó el espada con ambas manos e hirió al Donzel del Aventura por cima del escudo de tan poderoso golpe que entró por el brocal más de un palmo y le alcançó en la cabeça, y fue tan cargado que le hizo ir atrás con desconcertados pasos (...). (Felixmarte, pág. 192) ${ }^{15}$

Y la espada aferrada a dos manos, le hiere sobre el yelmo, que a pesar de nuestro cavallero, con la cabeça le hizo dar sobre las ancas de su cavallo. Y con gran furia, espantado del ruido, tirando coces aparta a su dueño de su enemigo. (Segunda parte de Espejo de príncipes y caballeros, pág. 280)

A veces ambos guerreros deciden golpear a la vez a dos manos a su adversario:

entrambos a vn tiempo alçaron sus temerosas espadas y con ellas tales golpes se dieron (...). (Belianís, vol. I, págs. 213-214)

${ }^{15}$ Sigo la edición de M. ${ }^{\text {a }}$ del Rosario Aguilar Pardomo (Melchor de Ortega, Felixmarte de Hircania, Alcalá de Henares, Centro de Estudios Cervantinos, 1998). 
desseando abreuiar la batalla, los escudos hechados a las espaldas, con las espadas a dos manos se hirieron tan braua y furiosamente que los yelmos, aunque de fino azero heran, fueron falsados, las espadas llegaron a las cabeças haziendo sentir el dulce cortar de sus filos y reboluiéndose prestamente con otros, el príncipe de Persia dio tres o quatro passos como desatinado por caer y don Belianís hincó la vna rodilla en tierra (...). (Belianís, vol. II, pág. 207)

Y levantándose los dos sobre los estrivos, se dan a un mesmo tiempo por encima de los yelmos tan poderosos golpes que el Caballero del Febo dio con el príncipe Meridián del cavallo abaxo, tan fuera de su acuerdo y sentido que no meneava pie ni mano más que si fuera muerto. Y fue tan grande y de tanta fuerça el golpe que el príncipe le dio a él, que todo el cuerpo le hizo abaxar hasta el pescueço del cavallo, y el yelmo le derribó de la cabeça. (Espejo de príncipes y caballeros, vol. III, págs. 195-196)

Y viendo que en ellos havía ya poca defensa, echando en tierra lo que les havía quedado, tomando las espadas a dos manos, y con grandíssima furia y saña de sí mesmos, se dan los siguientes golpes por encima de los yelmos con tanta furia que las cabeças se hizieron abaxar hasta los pechos, lançando grandes centellas de fuego de los finos yelmos. (Espejo de príncipes y caballeros, vol. I, pág. 169)

Apressurava con estos pensamientos sus golpes desesperadamente, pero aunque de la segunda acometida avía dos horas que peleavan, ninguno sentía flaqueza en su enemigo, antes con nuevo furor a una con entrambas manos alçan sus espadas, dexándolas caer con tanto poder sobre sus yelmos que entrambos a dos sin sentido cayeron en el suelo, creyendo los que los miravan que ambos fuessen muertos, según la abundancia de sangre que por las viseras arrojavan. (Segunda parte de Espejo de príncipes y caballeros, pág. 252)

Se trata de un momento de máxima tensión en el combate, del que puede esperarse el final de la contienda con la muerte de uno de ellos (a veces se teme por la vida de ambos contendientes). Pero no siempre sucede así: a veces tan sólo se consigue que se desvanezcan los dos caballeros, de forma que los caballos los llevan de un lado para otro hasta que los guerreros recuperan el conocimiento. Esto puede salvar la vida al caballero inconsciente, si su cabalgadura lo aleja de su enemigo; aunque el caballo también puede llevar a su jinete cerca de su contrincante y arriesgar así su vida ${ }^{16}$.

Si el caballero que ha perdido el conocimiento se recupera, la batalla suele continuar con mayor virulencia que nunca, puesto que o bien el caballero se enfurece y desea vengarse de su contrario, o bien, conociendo el peligro en que ha estado, decide luchar todavía más bravamente ${ }^{17}$.

${ }^{16}$ Cuando se da más de un enfrentamiento, en estas circunstancias puede producirse un cambio de contrincante, o bien puede aparecer un caballero que pretenda impedir que se mate al guerrero inconsciente.

${ }^{17}$ Un grado inferior a la pérdida del conocimiento es el aturdimiento que lleva al caballero a dar pasos desatinados e incluso a arrodillarse hasta que se recupera del todo. No se trata de un desmayo total, pero sí de una momentánea pérdida del equilibrio. 
Si tampoco con las espadas se impone claramente uno de los guerreros, entonces se pasa al tercer estadio del combate, la lucha cuerpo a cuerpo o combate «a brazos», que es una de las posibilidades a las que también puede recurrirse si se ha perdido la espada ${ }^{18}$.

Durante la lucha «a brazos» normalmente los contendientes pierden el equilibrio y caen. Se dedican entonces a intentar derrotar a su adversario simplemente con la fuerza de sus brazos. De la lucha cuerpo a cuerpo puede volverse al combate de espadas, si es que ambos todavía la conservan, pero muchas veces supone el fin para uno de ellos a manos del otro, su derrota o el momento en que la batalla se detiene por algún motivo. En ocasiones, una tercera persona les ruega que abandonen la lucha; también es posible que los guerreros hayan luchado sin reconocerse y sean en realidad amigos o parientes, de forma que, cuando por fin se enteran de la identidad de su contrincante, lamenten haber luchado ${ }^{19}$.

Todas estas posibilidades y esquemas se encontraban a disposición del escritor de libros de caballerías, quien los conocía perfectamente, de manera que formaban parte de una serie de convenciones bélicas que tendía a asumir a la hora de componer una batalla. Esta casuística no agota las posibilidades ni mucho menos, pero nos ayuda a acercarnos a la representación del combate en el género que nos ocupa, una representación que se apoya en la coherencia con una serie de expectativas del receptor y no tanto en la realidad bélica de su momento histórico (aunque, lógicamente, no hemos de descartar la influencia puntual de la realidad en estos reflejos literarios del combate ${ }^{20}$ ). Esas expectativas del receptor son precisamente a las que hemos pretendido acercarnos con la casuística expuesta. De esta manera comprendemos mejor la forma como el ventero cervantino (y, claro está, el propio Cervantes y otros lectores de libros de caballerías) percibían de estas obras.

${ }^{18}$ En todo este proceso bélico se observa un acercamiento paulatino al contrincante. Desde el encuentro de lanzas (con su necesaria previa carrera de caballos), pasando por un término medio (el combate con espadas) hasta el enfrentamiento cuerpo a cuerpo (trabados de los brazos), en el que la distancia entre los guerreros es nula.

${ }^{19}$ Por poner tan sólo unos ejemplos, recordemos el Belianís de Grecia, donde el héroe lucha contra su padre hasta que se reconocen. Lo mismo sucede en la Segunda parte de Espejo de príncipes y caballeros entre Claridiano y su padre Alfebo. En el Tristán, el héroe lucha contra su amigo Lanzarote pensando que se trataba de su enemigo Palomades. La lista podría alargarse, ya que la lucha entre amigos y, claro está, entre padre e hijo, es lugar común conocido. En estos casos, la similitud de fuerzas y coraje entre ambos contendientes implica que la batalla ha de ser extraordinariamente dura.

${ }^{20}$ Con respecto a la interrelación entre realidad y literatura caballerescas, vid. Martín de Riquer, Caballeros andantes españoles, Madrid, Espasa-Calpe, 1967. 


\section{LOS TÓPICOS}

En el apartado anterior se ha pretendido caracterizar el arte de la guerra en los libros de caballerías, esto es, las técnicas bélicas que — claro está, dentro de la ficción - utilizan los guerreros. Pero, para la representación literaria de esa «arte de la guerra» el autor contaba con una serie de tópicos heredados de la tradición caballeresca, tópicos que, a medida que avanza el siglo XVI, se van convirtiendo en unidades de composición que, a veces de forma encadenada, pueden llegar a conformar una especie de falsilla básica de construcción literaria de la lid singular. Esos tópicos bélicos, más allá de la simple recurrencia, se convierten en verdaderos materiales de construcción que permiten al escritor enfrentarse al reto de narrar algo tan complejo como es una batalla.

Esos lugares comunes funcionan en un doble sentido. Por un lado, forman parte del conjunto de probabilidades que ofrece el arte de la guerra propia del género caballeresco, esto es, funcionan como la realización de una serie de posibilidades teóricas que ofrece la tradición literaria (y una determinada visión de la realidad bélica). Por otro lado, en el plano textual, funcionan como unidades de construcción, una especie de material literario preestablecido que le sirve al autor para componer el relato del combate.

Como ya dijimos, en primer lugar se produce el encuentro de lanzas. Los caballeros se sitúan uno frente a otro y, a todo correr de sus caballos, intentan golpear a su adversario con la lanza. La carrera es tal que la tierra parece temblar:

movió el uno contra el otro al más correr de sus cavallos con tan gran poder que no parecía sino que la tierra tremía. (Primaleón, pág. 177)

Y corriendo con un impetuoso y arrebatado ruido, que parecía hundirse la tierra, se vinieron a encontrar (...). (Espejo de príncipes y caballeros, vol. 1, pág. 202)

se vino el uno para el otro al más correr de sus cavallos que parecía que la tierra temblava (...). (Leandro el Bel, fol. 51va).

E toda la tierra por do passavan hazían retemblar. (La Trapesonda, pág. 392 $)^{21}$

Tal como afirmó Martín de Riquer, el encuentro de lanzas conlleva, casi de forma inevitable y tópica, la quiebra de éstas ${ }^{22}$ :

${ }^{21}$ Sigo la edición de M. ${ }^{\text {a }}$ Carmen Marín Pina de Primaleón, Alcalá de Henares, Centro de Estudios Cervantinos, 1998. Tomo la cita de La Trapesonda de la edición de José Manuel Lucía Megías en su Antología de libros de caballerías castellanos, Alcalá de Henares, Centro de Estudios Cervantinos, 2001, págs. 390-394.

22 Además de las ediciones mencionadas, utilizo las siguientes: Garci Rodríguez de Montalvo, Sergas de Esplandián, Carlos Sainz de la Maza, ed., Madrid, Castalia, 2003; Feliciano de 
y firiéronse de las lanças en sus escudos tan bravamente, que ligeramente fueron quebradas (...). (Amadís, pág. 876)

diéronse tan grandes encuentros en los escudos que las lanças quebraron sin que mucho lo sintiessen (...). (Sergas, pág. 249)

encontráronse tan poderosamente que ambos a dos quebraron sus lanças y fueron a tierra (...). (Primaleón, pág. 78)

Las lanças fueron boladas en pieças (...). (Lisuarte de Grecia, pág. 39)

firiéronse tan duramente [de forma que fueron] las lanças hechas pieças (...). (Clarián, fol. $78 \mathrm{r}$ b)

las lanças hizieron bolar en pieças (...). (La Trapesonda, pág. 392)

las lanças en los escudos fueron rompidas (...). (Tercera parte de Florisel de Niquea, pág. 22)

Y en medio de aquella plaça se encontraron de suerte que los seguros escudos $\mathrm{y}$ arneses fueron falsados juntamente con las lorigas, las cuchillas de las lanças llegaron a las carnes donde si no quebraran no menos que de las vidas fuera el remate de la peligrosa justa comprado (...). (Belianís, vol. II, pág. 45)

Donde sonada que fue una tronpeta, los cavallero fueron al $<$ al $>$ más cor[r]er de sus cavallos el uno contra el otro y entranbos se encontraron y quebraron sus lanças en muchas pieças. (Felix Magno, vol. I, pág. 199)

y encontráronse tan poderosamente en medio de los escudos que bolando las lanças en muchas pieças se juntaron de los cuerpos de los cavallos (...). (Cirongilio, fol. 18rb)

aquellas gruessas lanças, que parescían vigas, rompidas fueron en los finíssimos arneses de los cavalleros, que en muy menudas astillas parescían subir a la región del aire (...). (Espejo de príncipes y caballeros, vol. I, pág. 202)

las lanças bolaron por el aire en menudas pieças (...). (Felixmarte, pág. 418)

mas ellos aviendo rompido sus lanças, se dieron tales encuentros de yelmo y escudo qu'el Príncipe de Macedonia hizo algún tanto desvanecer al Cavallero de las Flores (...). (Leandro el Bel, fol. 51va)

las lanças se hizieron menudos pedaços y las rajas parecían subir hasta las nuves (...). (Olivante, pág. 768)

las lanças, aunque gruessas, hechas pieças menudas se esparzieron por el aire (...). (Segunda parte de Espejo de príncipes y caballeros, pág. 32)

Silva, Lisuarte de Grecia, E. J. Sales-Dasí, ed., Alcalá de Henares, Centro de Estudios Cervantinos, 2002; Gabriel Velázquez de Castillo, Clarián de Landanís, Sevilla, Jacobo Cromberger, 1527; Feliciano de Silva, Florisel de Niquea (Tercera parte), Javier Martín Lalanda, ed., Alcalá de Henares, Centro de Estudios Cervantinos, 1999; Bernardo de Vargas, Cirongilio de Tracia, Sevilla, Jacome Cromberger, 1545. 
En las expresiones para indicar la ruptura de las lanzas el verbo más utilizado es «quebrar», tanto en voz activa como en voz pasiva, y suele especificarse «en pieças» («en pedaços»; «en astillas»); en menor medida se hace referencia al lugar golpeado, donde se quiebran las lanzas, normalmente en el escudo del contrincante. Otro verbo frecuente es «bolar», también con la frecuente especificación «en pieças», normalmente caracterizadas como «menudas», y —de nuevo con la intención de resaltar la dureza del impacto- se menciona que dichas piezas o astillas vuelan por el aire hasta alturas insospechadas.

En ocasiones, los guerreros no sufren en absoluto por tamaño golpe ${ }^{23}$. Otras veces tan sólo uno de los contendientes se mantiene en la silla:

mas del encuentro de don Duardos fue Nafante en tierra, tan poderosamente le encontró y passó por él don Duardos, muy apuesto cavallero a maravilla (...). (Platir, pág. 115) ${ }^{24}$

$\mathrm{Y}$ aunque muy fuerte y valiente fuesse, el francés era tal que del primer encuentro dio con él en tierra, passando él muy apuesto cavallero, sin recebir daño alguno. (Espejo de príncipes y caballeros, vol. IV, pág. 234)

La expresión «pasar muy apuesto caballero por [alguien]» quiere decir que el encuentro de lanzas no consigue ni derrocarlo ni moverlo de la silla. Otra expresión utilizada es «sin hacer mudanza», o «passar sesgo»:

sin hazer mudança los cavalleros, antes sesgos passaron el uno por el otro sin hazerse daño. (Segunda parte de Espejo de príncipes y caballeros, pág. 232)

Pero no siempre los caballeros pueden mantener la compostura tras el impacto de la lanza enemiga, sino que no pueden evitar bajar la cabeza hasta el pecho ${ }^{25}$, agarrarse al cuello del caballo o dar en el arzón trasero ${ }^{26}$.

En cualquier caso, una vez destrozadas las lanzas, los guerreros han de servirse de otra arma: la espada. Si los caballeros siguen sobre sus caballos, tienen que girar para volver a estar frente a su enemigo:

e diéronse tan fuertes encuentros que las lanças hizieron bolar en pieças; pero ellos no se movieron en las sillas, e los cavallos muy furiosos passaron adelante; pero ellos prestamente los boltearon. (La Trapesonda, pág. 392)

${ }^{23}$ Vid. también los ejemplos de la nota 7. 1997.

${ }^{24}$ Platir, M. ${ }^{a}$ Carmen Marín Pina, ed., Alcalá de Henares, Centro de Estudios Cervantinos,

25 «E fuéronse a dar tan mortales golpes que las cabeças se hazían baxar contra tierra el uno al otro» (Tristán, pág. 142); «hiriéndose tan brauamente que las cabeças hasta los arzones se hazían abaxar» (Belianís I, pág. 213); «Y juntándose se dieron tales golpes que las cabeças se hicieron baxar hasta los pechos» (Leandro el Bel, cap. 41, fol. 51vb).

${ }^{26}$ Vid. nota 8. 
Y dando buelta a sus cavallos, con las espadas en las manos y sus escudos embraçados se acometen reziamente, (...). (Espejo de príncipes y caballeros, vol. IV, pág. 110)

Y aún no avían bien los furiosos cavallos su larga carrera acabado quando bolviendo las riendas, les dieron buelta con estraña ligereza en el aire. (Espejo de príncipes y caballeros, vol. III, pág. 273)

y aun no parescía que los furiosos cavallos uviessen bien acabado la impetuosa carrera que llevavan, cuando de un ligeríssimo salto dan buelta en el aire; y los dos cavalleros con las espadas en las manos se acometen (...). (Espejo de príncipes y caballeros, vol. III, pág. 192)

Y viendo cada cual el poco movimiento que al contrario avía hecho con el encuentro, con las espadas en las manos rebuelven sus cavallos, donde se comiençan a golpear de tal suerte que las carnes sentían la braveza de sus braços. (Segunda parte de Espejo de príncipes y caballeros, pág. 32)

También con la lucha con espadas los golpes pueden hacer que los guerreros se vean forzados a bajar la cabeza hasta el pecho, a veces expresado de forma irónica:

los cuales, las espadas altas, a una se hirieron en los yelmos, de manera que a su pesar se uvieron el uno al otro de hazer obediencia como a grandes señores que eran se devía. (Segunda parte de Espejo de príncipes y caballeros, pág. 280)

Con la lucha de espada se considera, por tanto, que ha comenzado una nueva etapa del combate, momento que se suele considerar adecuado para caracterizar la batalla:

e pusieron manos a las espadas, e fuéronse a ferir el uno al otro bravamente. (Tristán, pág. 23)

y començaron entre sí una brava batalla (...). (Amadís, pág. 883)

començaron entre sí la más brava batalla que nunca por hombres en ninguna sazón vista fue (...). (Sergas, pág. 250)

començáronse de ferir d'esquivos golpes. (Primaleón, pág. 177)

començaron entre sí muy brava batalla (...) (Lisuarte, pág. 29)

entonces se començó entre ellos la más fiera y brava batalla que hombre podía ver (...). (Clarián, fol. 78r b)

y comiençan entre sí una brava y peligrosa batalla (...). (Tercera parte de Florisel de Niquea, pág. 112)

entre ellos se començó la más cruel batalla que en todo el día auía sido (...). (Belianís, vol. I, pág. 213)

entrellos se rebuelue vna batalla tan braua que quienquiera que los viera pensara ser la flor de la cauallería del mundo junta (...). (Belianís, vol. II, pág. 99) 
Y echaron mano a sus espadas y començaron su batalla asaz brava (...). (Felix Magno, vol. I, pág. 199)

metiendo mano a sus espada[s] se vinieron el uno contra el otro con grande saña, començáronse a herir por todas partes tan bravamente (....). (Cirongilio, fol. 18rb)

comiençan entre sí la más furiosa y espantosa batalla que jamás de dos cavalleros hasta su tiempo fue vista (...). (Espejo de príncipes y caballeros, vol. 1, pág. 203)

y de allí comiençan una batalla tan peligrosa y cruel que todos estavan admirados (...). (Leandro el Bel, fol. 51vb)

Y de allí comiençan una batalla tan cruel que espanto ponía a todos los que la miravan. (Leandro el Bel, fol. 117va)

En esto començaron entre sí una tan brava y ferocíssima batalla que todos los que la veýan dezían que jamás otra semejante de dos cavalleros avían visto (...). (Olivante, pág. 769)

Aquí començó una temerosa batalla (...). (Segunda parte de Espejo de príncipes y caballeros, pág. 232)

Durante esa batalla se incide sobre los aspectos de la ofensa, sobre las consecuencias destructivas del combate, que se muestran en la violencia con que se destrozan las armas. Las armas defensivas resultan «falsadas», esto es, atravesadas; los yelmos son abollados, los escudos, rajados y las cotas, desmalladas:

E dávanse tan grandes golpes que los pedaços de las armas andavan por el suelo (...). (Tristán, pág. 142)

Ellos cortavan los escudos, haziendo caer en el campo grandes rachas, y abollavan los yelmos y desguarnecían los arneses (...) hizieron sus armas tales que eran de poco valor (...) en los escudos no quedava con que cubrir ni ampararse pudiessen (...). (Amadís, pág. 319)

los escudos eran fechos pedaços y las lorigas desmalladas y rotas por muchos lugares (...). (Sergas, pág. 250)

fazían ambos a dos maravillas que rajavan los escudos y desmallavan las lorigas de los fuertes golpes que se davan. (Primaleón, pág. 177)

firiéndose tan duramente y con tanta fuerça que desmallavan sus lorigas, rajavan los escudos, abollavan los yelmos (...). (Clarián, fol. 13v b)

se comiençan a herir con estraña furia y braueza cortando los escudos y arneses, desmallauan las lorigas, (...). (Belianís, vol. II, pág. 208)

y las armas eran por muchas partes rotas y la carne con ellas y sus escudos pararon tales que no avían ya defensa ninguna, ni señal de estrella ni otra cosa (...). (Felix Magno, vol. I, pág. 193)

y era tanta la malla y las pieças que de los arneses avían perdido que sin raja de escudos peleavan como desnudos (...). (Cirongilio, fol. 18rb) 
rajándose los escudos, cortando y daspedaçándose las armas, sembrando el campo de las mallas de las lorigas (...). (Leandro el Bel, fol.51vb)

No es infrecuente la mención a la cantidad de sangre perdida por los guerreros:

y sus carnes cortadas, por donde mucha sangre les salía (...). (Amadís, pág. 883)

Tanta sangre les salía que el campo hazía tinto (...). (Sergas, pág. 250)

el campo donde se combatían en muchas partes era tinto de la sangre que d'ellos corría (...). (Clarián, fol. 13v b)

començando a poblar el espantoso b(r)alle de su sangre (...). (Belianís, vol. II, pág. 208)

Los dos cavalleros andavan en su batalla y entrambos perdían mucha sangre (...). (Felix Magno, vol. I, pág. 193)

hiriéndose por todas partes del cuerpo, assí que el campo era cubierto de la sangre que salía de sus llagas. (Cirongilio, fol. 18rb)

la sangre dava señal de las heridas que tenían (...). (Leandro el Bel, fol. 51bv)

Además de estas consecuencias destructivas, el autor pretende transmitir los aspectos sensoriales con hipérboles, de forma que de los yelmos salen centellas que ciegan a los presentes o incluso provocan la sensación de fuego:

en tal manera se davan los golpes de las espadas que fuego salía de los yelmos (...). (Tristán, pág. 124)

sus golpes eran tan fuertes y tan apriessa, que las llamas de fuego de los yelmos y de las espadas fazían salir que semejavan que ardían (...). (Amadís, pág. 877)

E diéronse muy grandes y esquivos golpes de las espadas sobre los yelmos, que el fuego en bivas llamas hazían en ellos encender (...). (Sergas, pág. 277)

dándose mortales golpes que la lumbre fazían salir de los yelmos (...). (Primaleón, pág. 78)

diéronse ambos a dos tan grandes y fuertes golpes por cima de los yelmos que las llamas encendidas hizieron saltar de entre ellos y las espadas (...). (Clarián, fol. 78r b)

Sus golpes heran tan fuertes y tan apriessa que las llamas de fuego de los yelmos y espadas hazían sallir en tanta abundancia que parescían arder (...). (Belianís, vol. II, pág. 99)

Mas levantándose comiençan una batalla que las centellas les salían muy bivas de las armas y aun a vezes tantas que los que los vían los perdían muchas vezes de vista. (Leandro el Bel, fol. 65rb) 
Por otra parte el ruido semeja el de una batalla entre gran cantidad de guerreros, o se oye a una enorme distancia:

El ruido de los golpes era tal como si allí veinte cavalleros se firiesen (...). (Sergas, pág. 250)

el reteñir de las espadas era tan grande que no parescía sino que diez cavalleros se combatiessen (...). (Clarián, fol. $78 \mathrm{r}$ b)

tal era el ruido de las armas como cuando un exército con otro rompe (...). (Cirongilio, fol. 18rb)

La duración es un dato sobre la dificultad de un determinado combate, ya que, cuanto más dura resulta una batalla, tanto más prolongada será:

E cuando fueron una gran pieça combatidos, ellos se tiraron afuera (...). (Tristán, pág. 124)

Assí duraron en esta primera batalla hasta hora de tercia (...). (Amadís, pág. 320)

Los cavalleros anduvieron en su batalla bien una hora sin descansar ni hazer otra cosa salvo darse los más esquivos y duros golpes que ellos podían (...). (Sergas, pág. 250)

anduveron una ora dándose mortales golpes (...). (Primaleón, pág. 78)

ansí anduuieron en tan gran priessa como oýs, dándose muy grandes, espessos y esquiuos golpes hasta que quería amanescer (...). (Belianís, vol. II, pág. 100)

$\mathrm{Y}$ assí anduvieron gran pieça, tanto que los cavallos no los podían traer de cansados (...). (Felix Magno, vol. I, pág. 200)

Más de una hora anduvieron el uno y el otro sin tomar punto de descanso alguno. (Leandro el Bel, fol. 65va)

Junto con la alusión al tiempo que combaten los guerreros, en ocasiones se menciona que no se percibe ventaja entre ellos, lo que aumenta la tensión del relato ${ }^{27}$ :

Mas los cavalleros anduvieron firiéndose por todas partes si[n] un punto descansar un ora grande, que ninguna mejoría se podía conocer del uno al otro (...). (Sergas, pág. 277)

$\mathrm{Y}$ anduvieron ansí gran pieça sin que en ninguno se paresciese punto de mejoría (...). (Primaleón, pág. 177)

Desta guisa anduuieron en la batalla por espacio de quatro horas sin conocerse mejoría (...). (Belianís, vol. II, pág. 208)

27 Y justifica que se hable, en general, de los dos guerreros, sin especificar las acciones de ninguno de ellos, ni mencionar ningún golpe en concreto. 
anduvo en su batalla gran pieça que en los dos cavalleros no se conocían ventaja el uno al otro (...). (Felix Magno, vol. II, pág. 9)

de esta manera anduvieron cerca de otra ora sin sentirse mejoría ni menos cansancio alguno (...). (Leandro el Bel, fol. 117va)

Ante una lucha tan larga, los guerreros terminan perdiendo la paciencia; su ira aumenta al ver que no son capaces de derrotar a su adversario tan rápidamente como pensaban. En ese momento suelen echar los escudos a las espaldas - para manejar la espada con las dos manos_ y, si están a caballo, ponerse sobre los estribos — para intentar golpear desde mayor altura-, buscando el golpe más efectivo, como ya dijimos. Se trata de una tentativa de acortar un combate que resulta excesivamente prolongado, un intento de terminar con la vida del enemigo de un único golpe y acabar así la lucha.

Otra forma de indicar la dificultad de la batalla es comentar las impresiones de los que observan el combate. Por ello es tan frecuente que se mencione a los testigos del enfrentamiento. Puede ser una referencia bien a un personaje o personajes específicos, bien al conjunto de personas que están presenciando el combate (resulta frecuente la fórmula: todos / quienes + los que los miravan / los que estaban alrededor); pero también puede ser una referencia a los testigos potenciales (quienes lo vieran). Estos testigos, asombrados y «espantados» contemplan el combate, y consideran que es uno de los más bravos que han visto:

fuéronse dar grandes golpes que todos se maravillavan de los ver (...). (Tristán, pág. 23)

E quien aquella batalla vio, bien puede dezir que no vio su par (...). (Tristán, pág. 144)

fuéronse a ferir tan bravamente, que no ha hombre que los viesse que mucho no se espantasse (...). (Amadís, pág. 877)

los que alderredor estavan havían espanto de los ver (...). (Amadís, pág. 318) espanto grande ponían a aquellos que de la nave los miravan (...). (Sergas, pág. 277)

Y todos cuantos aquella batalla vieron dezían que jamás la avían visto más cruel ni peligrosa. (...). (Primaleón, pág. 177)

sus escuderos que la batalla miravan estavan espantados e no sabían qué remedio poner (...). (Clarián, fol. $78 \mathrm{r}$ b)

Qué vos diremos de la admiración de los que estavan presentes y más de aquellos que en caso de batallas más se le entendía, salvo que les parescía que ninguna otra cosa ygual jamás ouiessen visto (...). (Belianís, vol. II, pág. 234)

los que los miravan eran espantados. Y dezían que nunca avían visto batalla de dos cavalleros que tan rezia fuese (...). (Felix Magno, vol. I, pág. 192) 
los que los miravan estavan maravillados (...). (Cirongilio, fol. 18rb) todos estavan admirados, (...). (Leandro el Bel, fol. 51vb)

y, en ocasiones, con sus comentarios destacan la dureza del combate y la fuerza de los guerreros. Pero también los propios contendientes pueden reconocer el vigor y coraje del contrario:

E d'esta primer batalla se dieron tan grandes golpes que dixo Morlot entre sí: -Aquéste no da golpes de moço, antes los da como hombre de fuerça e gran coraçón. (Tristán, pág. 23)

E el cavallero dezía que nunca tamaños golpes recibiera, mas no dio a entender qu'él se espantava. (Tristán, pág. 143)

El gran cavallero era espantado de los grandes golpes que el cavallero le dava y así mismo Arpio era maravillado de la bondad de su enemigo (...). (Felix Magno, vol. II, pág. 28)

y cada uno mirava a su contrario maravillado de su gran valor, ca ninguno d'ellos creyera que un solo cavallero tanto le durasse en el campo. (Cirongilio, fol. 18rb)

Cuando se produce alguna interrupción del combate, por un momentáneo descanso de los contendientes, por el diálogo entre ellos o de los testigos, o por cualquier otro motivo (por ejemplo, dejar el caballo para enfrentarse a pie), se reitera la dureza de la batalla cuando vuelven a ella:

Y cometiéronse muy más sañudos que ante, y tan bravo se herían como si entonces començaran la batalla y aquel día no ovieran dado golpe (...). (Amadís, págs. 320-321)

Estonces se acometieron como de ante (...). (Amadís, pág. 883)

Estonces se fue el uno al otro y tornaron a su batalla con mucha más saña y fuerça que de primero (...). (Sergas, pág. 250)

y tornaron a començar su batalla como primero (...). (Primaleón, pág. 78)

E no ovieron mucho descansado cuando tornaron a su batalla como de primero (...). (Clarián, fol. 13v b)

Y començaron su batalla a pie tan reziamente como si entonces començaran aquella batalla (...). (Felix Magno, vol. II, pág. 28)

A esta sazón se esforçó tanto su batalla que no parescía si no que de nuevo començavan. (Cirongilio, fol. 18rb)

Cuando los guerreros se detienen a tomar aliento, se da por finalizada una etapa del combate, de forma que, cuando retornan a él, se habla de una segunda batalla, y así sucesivamente. Cada acometida se contempla, por tanto, como una unidad de lucha. 
En resumen, son numerosos los tópicos que se encuentran al alcance del escritor que quiere componer un combate. Entre estos lugares comunes son especialmente frecuentes los siguientes:

1. Los caballeros cabalgan a toda prisa, de forma que la tierra parece temblar.

2. Las lanzas se quiebran, se hacen astillas o vuelan.

3. Tras el primer encuentro de lanzas y si se mantienen sobre sus cabalgaduras, dan la vuelta a los caballos con ligereza.

4. Tras haber perdido las lanzas, «aquí comienzan una hermosa batalla».

5. Las armas resultan destrozadas, y sus piezas terminan sembradas por el suelo, (los escudos, rajados o falsados; los yelmos, abollados; las lorigas, desmalladas).

6. Los golpes hacen que los guerreros bajen las cabezas hasta los pechos o se inclinen sobre el arzón trasero.

7. El ruido resulta atronador.

8. Salen centellas de los yelmos a causa de los golpes.

9. La batalla se prolonga durante largo rato.

10. No se percibe mejoría ni cansancio entre los contendientes.

11. Tras un descanso, comienzan de nuevo con igual o mayor vigor (aprovechándose más de fuerza que de destreza).

12. Los testigos están admirados (e incluso asustados) de la crueldad de la lucha.

13. Los guerreros admiten la dureza del contrario e incluso se dicen que nunca han combatido contra otro igual.

14. Crece la ira de cada guerrero al ver que el contrario le dura tanto tiempo.

Todos estos lugares comunes pertenecen a la tradición y a la práctica literarias, y no a las retóricas, que nunca los recogieron en sus páginas. En cualquier caso, la identificación de estos tópicos nos permite comprender la composición de los relatos de combates en los libros de caballerías.

TÉCNICAS NARRATIVAS: DE LA CARACTERIZACIÓN GENERAL AL RELATO PORMENORIZADO

El autor que pretende representar literariamente un combate en un texto caballeresco se enfrenta a una serie de retos cuya solución revela la multiplicidad de medios a los que se puede recurrir.

La forma más simple de narrar un combate es la afirmación de la acción (lucharon) y la afirmación del vencedor y/o vencido (lo mató; lo derribó; lo derrotó). Pero puede añadirse más información a este esquema mínimo, hasta llegar a la narración pormenorizada; nos encontramos ante un relato pormenorizado de un enfrentamiento armado cuando el autor da cuenta de todas y cada una de las acciones de los combatientes; de esta manera, no se oculta ninguno 
de los movimientos ni reacciones de los personajes y se nos narran todos los golpes y sus consecuencias punto por punto. En este caso se nos ofrecen todos los detalles: se define el golpe (con qué, cómo y dónde se golpea) y sus consecuencias, tanto su éxito (los daños en el físico del contrincante, en su caballo o en sus armas) como su fracaso (los golpes fallidos por una rápida reacción del contendiente o por otros motivos). El autor ha analizado la acción — la lucha- en sus partes constitutivas esenciales — golpear y esquivar/recibir el golpe- a las que se añaden las consecuencias, y se ofrece información del tiempo —duración del combate - y del espacio — lugar del combate—, así como referencias al pensamiento y a la actitud de los contendientes.

Entre estos dos polos, se encuentra toda una serie de grados a los que recurre el escritor para construir textualmente el combate. Dentro de esta serie de grados, el autor puede optar por ofrecer una descripción general, una imagen de conjunto de la batalla a través de adjetivos (cruel, descomunal, brava, esquiva, sangrienta, áspera, entre otros), mencionando la importancia o gravedad de los golpes, comentando las tácticas de cada uno de los guerreros, pero sin narrar de forma individualizada ningún golpe en particular ni ninguna herida determinada, porque se tiende a hablar, a la vez, de los dos contendientes, que funcionan como el sujeto plural de buena parte de los verbos. De esta manera, no se singulariza la actividad de ninguno de ellos. Un ejemplo de este tipo de relato del combate lo encontramos en Felixmarte de Hircania:

y encontráronse tan poderosamente que las lanças bolaron por el aire en menudas pieças y juntáronse de los cuerpos y los escudos, y diéronse tales golpes que ellos y sus cavallos vinieron a tierra. [...] Y como sintieron los cavalleros caer sus cavallos, guardáronse de suerte que a ninguno tomaron debaxo, y en un momento fueron en pie. Y sacados los troços que los escudos atravesavan, con las espadas en las manos, con gran saña de aver caído, se vinieron a herir de tan espesos golpes que a todos hizieron maravillar, porque haziendo salir vivo fuego de sus armas, tan ligeramente se las cortavan que los juzgavan por no bastantes para assegurar las vidas de aquellos que las traían. Y andando tan rebueltos que muchas vezes se desconocían, era tanto el ruido y priessa que apenas se juzgava la distancia que de un golpe a otro passava, de suerte que en breve espacio el campo fue lleno de mallas y pedaços de lorigas, y sus armas parecían llenas de sangre, y ellos tan llagados que muy en breve serían deshechos según sus ánimos y fuerças en un ser permanescían. Mas conociendo cada uno de los cavalleros la fortaleza de su contrario, para poder sustentarse començaron a usar de su gran destreza, de tal suerte que se hazían perder muchos golpes, y algunos se herían a su salvo, con tanto extremo que maravillosa cosa era de mirar, y los más diestros con embidia se admiravan. Y d'esta suerte, sin que entre ellos ventaja se conociesse, anduvieron tan gran pieça que impossible parecía poderlo tanto durar. Y enojados ya de se herir, vinieron a los braços y armávanse tales caídas que hazían parecer su batalla más peligrosa. [...] Y a esta hora, los cavalleros bolvieron a su batalla con tanto ardimiento como si en- 
tonces fuera el principio d'ella, y tan grande pieça anduvieron sin poderse hazer ventaja que los escudos fueron deshechos, y ellos tan llagados que no esperavan otra cosa que la muerte. [...] (pág. 418)

El combate singular se ha construido atendiendo simplemente a la caracterización global o general. Se evita la narración de acción y respuesta propia de la batalla y se comenta de forma conjunta la acción de ambos contendientes. Como se observa, el sujeto de los verbos es plural, pues se refiere a los dos guerreros.

Sin embargo, como hemos dicho, lo más frecuente es que todos estos procedimientos alternen.

En definitiva, las decisiones que ha de tomar el autor son: a) la longitud narrativa que quiere dar al combate y b) la concreción con que quiere narrarlo. Atendiendo a estos dos criterios, la batalla se relatará de una u otra forma. La comparación entre dos combates cualesquiera de dos obras caballerescas distintas (o incluso dentro de la misma obra) pone en evidencia las diferencias que pueden llegar a existir entre la forma de enfrentarse al mismo problema básico de narrar un acontecimiento complejo, como la batalla, constituido por multitud de unidades menores: ofensa (golpear) y defensa (esquivar el golpe o protegerse).

Puede comprobarse cómo el combate de Felixmarte de Hircania se encuentra en el campo de las expectativas que el lector de libros de caballerías tenía de la batalla. Por otra parte, el recorrido que hemos realizado por estos tópicos permite comprender el sistema seguido por Melchor de Ortega, quien ha asumido estos tópicos y lugares comunes para recrear una «brava batalla», y tan sólo ha tenido que optar por seleccionar alguno de éstos y decidir una solución lingüística determinada para expresarlos.

Aunque estos tópicos no siempre se dan juntos, resulta frecuente que aparezcan unidos como una falsilla para construir batallas literarias. Las variantes que el autor incorporaba a esta falsilla funcionaba como elemento sorpresa para el receptor, que captaría con enorme facilidad ese golpe o situación inesperados en un relato que, por tipificado, conocía a la perfección.

\section{CONCLUSIONES: EL RELATO BÉLICO COMO PIEZA LITERARIA}

El análisis detallado de la construcción textual nos obliga a reflexionar sobre los procedimientos, estrategias y recursos del arte de narrar; nos fuerza a centrarnos no en lo narrado (la macroestructura literaria), sino en la expresión lingüística - y literaria - concreta (la microestuctura). De esta forma, la palabra recobra el protagonismo y no se ve oculta por el velo de referentes mentales a los que nos lleva; se nos desvela así el esqueleto real de la obra literaria. 
El estudio pormenorizado de la narración del combate en los textos caballerescos nos lleva a una serie de conclusiones. En primer lugar, no todos los relatos de combates son iguales, es más, no hay dos combates que sean idénticos; si bien existe una serie de lugares comunes que los escritores pueden utilizar como material para componer sus propios relatos bélicos, prácticamente siempre transforman esos materiales de una forma personal o bien colocan esos materiales de forma original, con el fin de sorprender al lector, al tiempo que satisface sus expectativas.

Hemos constatado cómo cada autor muestra unas determinadas preferencias por ciertos tópicos, en detrimento de otros. Jerónimo Fernández, autor del $B e$ lianís de Grecia, se muestra proclive a indicar las consecuencias del encuentro de lanzas; así, sus caballeros se inclinan o caen del caballo. Frente a esto, Diego Ortúñez de Calahorra, autor del Espejo de príncipes y caballeros, tiende a acentuar la reciedumbre de sus guerreros, que suelen mantenerse impertérritos ante el impacto de la lanza enemiga. De ahí que en esta obra se hable de la rapidez y ligereza con que los contendientes dan la vuelta a sus caballos para continuar luchando con sus espadas.

Pero, al mismo tiempo, ambos autores muestran ciertas similitudes en cuanto a su estilo: tendencia a la exageración y la hipérbole, así como a las referencias mitológicas. Estas similitudes resultan más evidentes si comparamos el estilo de estos dos escritores, con el estilo de, por ejemplo, Melchor de Ortega, mucho más sobrio y menos dado a la hipérbole, al hipérbaton y a las alusiones mitológicas.

Las narraciones de la lucha evidencian las peculiaridades compositivas y estilísticas de cada autor, que tiende a utilizar unas fórmulas expresivas muy parecidas (si no idénticas en algunos casos), frente a otros escritores. Al mismo tiempo, también sirve para analizar la evolución estilística de autores como Feliciano de Silva, quien, partiendo de una sintaxis cercana a la de Montalvo, terminó con el complicado estilo parodiado por Cervantes. Por tanto, el análisis literario de estos relatos nos abre nuevos caminos a la investigación sobre la materia caballeresca, pero también sobre la prosa artística de esos siglos.

El relato del combate en estos textos se convierte - como la carta, el poema, el amanecer mitológico, las arengas militares o el retrato-, en una unidad compositiva en la que el escritor pretende dejar constancia de su talento literario. Esos relatos bélicos son piezas textuales que merecen también ser analizadas desde un punto de vista literario; sólo entonces podremos captar su originalidad y su valor como creación poética. 